right to access information is investigated; the multiple approaches of scientists to their definition are analyzed. It is established that among scientists there is no unity in defining the notions of «right to information» and «the right to access information», which leads to ambiguity of approaches to understanding of their correlation. Both in the legal doctrine and in the law are widespread views on the separation of the two approaches to the interpretation of the right to information: broad approach involves attributing to the right to information of all kinds of subjective rights directed towards information or actions with it; the narrow approach is identified with the right to obtain (access) information. Determined that in fact the term «right to information» has no legislative provisions. The Constitution of Ukraine and sectoral legislation contain only a list of relevant powers. The Basic Law establishes four such powers (collect, keep, use, distribute), and relevant sectoral legislation - five (to receive, use, distribute, keep, protect information). Approaches to the correlation between the right to information and the right to access information are determined. It is determined that in modern scientific literature there are several positions (approaches) concerning the relation of the right to information and the right to access information: the right to information is identified with the right to access information in a «narrow approach» to the definition of the right to information; the right to access information advocates as an integral part (element) of the right to information; the right to information and the right to access information are considered as independent human rights.

Key words: the right to information, the right to access information, information, human and civil rights, constitutional rights

DOI https://doi.org/10.33766/2524-0323.86.20-31

УДК 342.724 (4)

I. Ю. Животовська,

кандидат юридичних наук, старший викладач кафедри конституційного права

Національного університету

«Одеська юридична академія»

(м. Одеса, Україна)

e-mail: nauka910@i.ua

(iD https:/ / orcid.org/0000-0002-0280-2926

\title{
ЗАБОРОНА ДИСКРИМІНАЦІЇ НА НОСІННЯ РЕЛІГІЙНИХ СИМВОЛІВ В СУДОВІЙ ПРАКТИЦ ЄВРОПЕЙСЬКИХ РЕГІОНАЛЬНИХ СУДІВ
}

У статті автор аналізує прецедентну практику Суду Європейського Союзу, спрямованого на розгляд справ щодо носіння працівниками релігійних символів на робочому місці (Achbita v G4S Secure Solutions NV та Bougnaoui v Micropole SA), які стосуються релігійної дискримінації відповідно до Директиви про рівне ставлення 2000/78/СС. Згідно з міжнародними конвенщіями 3 прав людини, прагнення приватної компанії до нейтральної політики не може бути привідом для обмежень права на свободу віросповідання працівника на робочому місці. Проте Суд встановив, що за відповідних обставин компанія має право на ведення такої політики, результат якої спричиняе на практиці негативні наслідки для значної частини суспільства особливо для мусульман, сикхів та іудеїв, які стикаються з проявами дискримінації при працевлаштуванні. Особлива увага у статті приділяється досвіду Європейського Суду з прав людини при розгляді аналогічних справ. 
Ключові слова: права людини, свобода віросповідання, релігійна дискримінація, релігійні символи, нейтралітет, пропорційність, принцип рівності.

Постановка проблеми. Вплив європейської демократії поширений на кожен сегмент соціального суспільства і яскраво виражений у непростому питанні: релігія в Європі, яка за багато тисячоліть свого існування істотно змінилася - від хрестових походів проти «невірних» i «єретиків» до європейських релігійних воєн у XVII столітті, трагедії Голокосту XX ст. для придушення або знищення однієї релігійної групи чи іншої. Із закінченням Другої світової війни та проголошенням численних універсальних i регіональних угод щодо гарантій прав людини, вузьке розуміння захисту прав вірян перейшло в загальну сферу захисту прав людини.

Основні договори з прав людини містять положення про свободу релігії та заборону дискримінації за релігійною ознакою: статті 2 та 18 Загальної декларації прав людини (1948р.), стаття 18 Пакту про громадянські та політичні права (1966р.), статті 9 та 14 Європейської конвенції про захист прав людини та основних свобод (1950р.), стаття 12 Американської конвенції 3 прав людини (1969р.), стаття 8 Африканської хартії прав людини та народів (1981 p.).

Протягом 1960-х років у межах ООН робляться спроби ухвалити окрему конвенцію про свободу віросповідання, яка могла б служити засобом тлумачення та застосування чинних положень. Хоча робота над конвенцією не мала успіху, причому остання формальна спроба датується 1973 роком, Генеральна Асамблея ООН остаточно ухвалює Декларацію про ліквідацію всіх форм нетерпимості та дискримінації на основі релігії чи переконань у 1981 p.

Свободи «обирати, мати й змінювати релігію» в межах forum internum $€$ абсолютним правом, надійно обгрунтованим як на міжнародному рівні, так і в Свропі, проте ступінь, у якому вона може виявити своє зовнішнє вираження на робочому місці породжує багато міжнародних суперечок. Упродовж останнього десятиліття скарги осіб у обмеженні їхнього релігійного вираження подвоїлися та створюють середовище, у якому релігійні особи та члени релігійних меншин часто відчувають себе сторонніми в країнах проживання. Такій тенденції, імовірно, сприяють численні чинники, такі як посилення багатонаціональності європейського народу та наростання потоку біженців із різних країн світу, що принесли 3 собою, крім надії на поліпшення умов життя, культуру, цінності, традиції і релігії країни походження. Разом із поширенням мультикультурності християнська Європа зіткнулися із релігійним екстремізмом та його наслідками. Останнє призвело до форсованих закликів щодо заборони на носіння релігійного одягу або символів у громадських місцях або на певних державних чи приватних робочих місцях.

Правове регулювання носіння релігійного одягу (наприклад, мусульманський хіджаб, сикхський тюрбан, кіпа та цицит у іудеїв, християнський хрест) значно відрізняється між державами-членами Європейського Союзу, але часто використовується в прецедентному праві європейських регіональних судів. До того ж, у контексті зростання ісламофобії, коли для мусульманських жінок обмеження стають звичаєвою 
нормою, а свобода - відхиленням від загального правила, ці нововведення в європейській прецедентній практиці відкривають шлях до ще більшого вивчення цього питання.

Варто наголосити, що в Свропі проблема не стільки носіння хіджабу, скільки нікабу (вбрання, яке залишає відкритими лише очі). Причому декілька держав Європейського Союзу (Бельгія, Франція) взагалі перейшли на заборону нікабу в громадських місцях з метою посилення контролю за релігійною сферою життя після серії терактів у низці країн Європи. Відзначимо, що така заборона не поширюється на носіння хіджабу (канонічний одяг мусульманки, який укриває все тіло, крім обличчя, кисті рук).

Визнаємо, що практика релігійних переконань може перебувати в конфлікті з іншими правами, наприклад, із правом на рівність або правом на безпеку, охорону здоров'я. Ключовим моментом є те, чи таке обмеження має слугувати законній меті й може бути виправдане в плюралістичному демократичному суспільстві. Не можна не погодитися з тим, що нікому не слід відмовляти в роботі через наявність «неправильної» релігії; нікому не слід припиняти роботу через приналежність до мусульманської, християнської або будь-якої іншої віри чи переконань. Проте справи, у яких беруть участь мусульманські жінки, частіше всього не є успішними в Люксембурзі.

Аналіз останніх досліджень і публікацій. У межах цієї статі автор керувався окремими справами Суду Свропейського Союзу та Свропейського суду з прав людини щодо розгляду питань, безпосередньо пов'язаних із вираженням свободи віросповідання, при цьому питання носіння релігійних символів чи одягу на робочому місці не піддавалися безпосередньому науковому аналізу та потребують окремого дослідження.

Формування цілей. Метою цього дослідження є надання правової бази та деталей судової практики щодо дискримінації на робочому місці за ознакою релігії. У цій статті розглядаються рішення кількох ключових справ iз урахуванням трьох визначних проблем: право на свободу релігії та іï обмеження; релігійний одяг та дискримінація; релігійний секуляризм.

Виклад основного матеріалу. За преамбулою Хартії основних прав Свропейського Союзу [1] рівність є однією із цінностей, на яких грунтується Європейський Союз. Так, стаття 20 цього документу починається із чіткої декларації про те, що «кожен є рівним перед законом», однак застосування вказаного положення на практиці виявляється сумнівною формою рівності.

Варто також зазначити, що принцип рівного ставлення до релігії чи переконань містить Директива Ради 2000/78/ Свропейського Союзу від 27 листопада 2000 року, що встановлює загальні рамки для рівного ставлення у сфері праці та професійної діяльності як у публічному, так і в приватному секторах, включаючи державні органи [2]. Указана Рамкова директива про дискримінацію у сфері зайнятості набула чинності у 2003 році, але для того, щоб Суд вирішив винести своє перше важливе рішення щодо ії релігійних положень, знадобилося 14 років. 
Пряма дискримінація за Рамковою конвенцією має місце, якщо з однією особою поводяться гірше, ніж 3 іншою в схожій ситуації (ст. 2 (2) (а), наприклад, коли роботодавці взагалі відмовляються наймати на роботу людей певної релігії або приймають послідовників однієї релігії на більш вигідних умовах, ніж інших. Не може бути прямої дискримінації, якщо всі працівники підпадають під дію того ж дрес-коду, в такому випадку вони розглядаються однаково.

Непряма дискримінація має місце, коли вочевидь нейтральна умова, критерій або практика змусили особу певної релігійної приналежності або віросповідання опинитися в особливо незручній ситуації, порівняно 3 іншими особами, але згідно з законодавством Європейського Союзу це припустимо, якщо така умова, критерій або практика об' єктивно виправдані законною метою, а засоби, які використовуються для ії досягнення, повинні бути пропорційними й необхідними (ст. 2 (2) (b). Наприклад, роботодавець установлює вимоги 3 приводу уніформи або робочого часу, які важко дотримуватися послідовникам певної релігії, але згідно з законодавством СС це допустимо, якщо будь-які подібні вимоги матимуть законну мету й шляхи для ії досягнення є виправданими та прийнятними. Іншими словами, роботодавець може заборонити співробітникам носити головний убір на роботі лише за умовою, якщо він, по-перше, може довести, що існує справжня та визначальна професійна вимога, i, по-друге, ця вимога повинна бути «пропорційною» для досягнення «законної» мети. Суду важливо з'ясувати, чи була «нейтральна політика» напередодні звільнення працівника «справді послідовною та систематичною». Таким чином, заборона може являти собою пряму (якщо заборонено тільки мусульманські хустки) або непряму дискримінацію (якщо забороняються всі форми головних уборів).

Судова практика Суду Європейського Союзу (далі - Суд СС) щодо політики нейтралітету в приватних компаніях $є$ проблематичною в кількох перспективах. По-перше, важливо з'ясувати законну мету, на яку посилаються роботодавці. По-друге, варто критично розглянути аналіз пропорційності. Нарешті, важливо виявити роль, яку Суд $Є С$ може відігравати в майбутньому, коли йдеться про право людини виявляти свою релігію на приватному робочому місці.

14 березня 2017 року Суд СС виносить довгоочікувані рішення 3 двох справ - одне з Бельгії (Achbita проти G4S Secure Solutions NV (справа C-157/15) [3] та одне з Франції (Bougnaoui проти Micropole SA (справа C-188/15) [4], які призвели до плутанини та занепокоєння в деяких державах-членах щодо того, чи може роботодавець приватної компанії законно заборонити жінкам носити на роботі хіджаб і чи це порушує заборону релігійної дискримінації на робочому місці, що міститься в Рамковій директиві про трудову діяльність 2000/78/СС.

У першій справі пані Ахбіта після трьох років роботи в бельгійській компанії G4S заявила своєму керівнику, що вона має намір покривати голову ісламською хусткою (хіджаб) під час виконання своїх трудових функцій. Керівництво компанії G4S повідомило, що носіння хіджабу суперечить 
правилам нейтралітету внутрішньої політики компанії. Це було неписане правило, згідно з яким усі працівники повинні були утримуватися від носіння будь-яких візуальних знаків їхніх політичних, філософських або релігійних переконань. Згодом робоча рада схвалила нове письмове правило, що забороняє видимі ознаки релігійної віри. Таку вимогу роботодавця пані Ахбіта проігнорувала, у результаті чого була звільнена. Однак Суд ЄC зазначив, що в діях компанії відсутні ознаки прямої дискримінації, оскільки внутрішні правила визначають таку заборону без прив'язки до конкретної віри, правило стосується всіх працівників і трактується однаково.

Той факт, що Суд СС значною мірою покладався на визначення релігії виходячи зі статті 9 Свропейської конвенції, у цьому випадку не викликає проблем. Проте існують певні труднощі між правом на свободу віросповідання та ідеєю непрямої дискримінації на підставі релігії. Так Суд ЄC у справі пані Ахбіти аргументував, що хоча внутрішнє правило G4S, яке забороняє працівникам носити будь-які видимі політичні, філософські або релігійні ознаки на робочому місці, не є прямою дискримінацією згідно зі статтею 2 (2) (а) Директиви 2000/78/СС, воно може являти собою лише непряму дискримінацію (ст. 2 (2) (b), і продовжив оцінку того, чи загальна заборона на видимі релігійні атрибути була доречною й необхідною для підтримання нібито законної мети нейтралітету компанії. Суд критикували за застосування дуже м'якого тексту в справі Саміри Ахбіти.

При вирішенні цієї справи постало головне питання про те, чи звільнення працівника за носіння головного убору на робочому місці $\epsilon$ належним і необхідним засобом для досягнення нейтрального іміджу компанії щодо клієнтів. Суд визнав бажання роботодавця представити образ нейтралітету компанії клієнтам, як prima facie законну мету, що стосується свободи ведення бізнесу (закріплена в статті 16 Хартії основних прав Європейського Союзу), особливо у випадку тих працівників, «які повинні вступати в контакт з клієнтами роботодавця».

Як випливає 3 фабули другої справи «Bougnaoui проти Micropole» інженер-конструктор Асма Буняві була звільнена із консалтингової компанії Micropole після того, як клієнт поскаржився на носіння нею ісламської хустки. У справі пані Буняві Європейський Суд визнає пряму дискримінацію на підставі релігії, оскільки рішення роботодавця не грунтувалося на загальній політиці «нейтрального іміджу» компанії. Іншими словами, готовність роботодавця враховувати бажання клієнта не може вважатися справжньою та визначальною професійною вимогою в розумінні цього положення. Свропейський Суд є більш критичним у випадку з пані Буняві та визнає, що скарги клієнтів не достатньо, щоб роботодавець міг звільнити працівника, оскільки таке ставлення клієнтів є суб'єктивним та не пов'язане iз професійними навичками працівника. Зауважимо, що у випадку з пані Ахбітою така критична позиція була відсутня.

Це не перший випадок судових тяжб 3 приводу вираження працівниками релігійних атрибутів на робочому місці. Для порівняння, 
рішення Суду ЄС в справі Ахбіти суперечить судовій практиці Європейського Суду з прав людини, зокрема, у справі Евейда проти Сполученого Королівства 2013 р. [5], у якій Європейським судом з прав людини було визнано, що створення певного типу корпоративного іміджу авіакомпанії не повинно переважати над правом робітниці носити натільний хрестик, щоб висловити свою релігійну віру. У справі Евейди Європейський Суд з прав людини установив, що англійські суди не досягли «справедливого балансу» в захисті статті 9 Європейської конвенщії про захист прав людини й основних свобод: вони надавали занадто велику вагу роботодавцеві щодо корпоративного іміджу та недостатню вагу зацікавленості працівника у висловленні релігійних переконань через носіння релігійного символу, у цьому випадку - хрестика. Варто зауважити, що в нинішньому контексті статті 9 аналіз пропорційності виявляється ключовим.

Рішення Суду $Є С$ та Європейського Суду з прав людини повинні повністю відповідати законодавству Європейського Союзу й забезпечувати недискримінацію для всіх членів різноманітного та плюралістичного суспільства Європи. Більш того, створюється ризик розколу між судовою практикою Суду в Люксембурзі та Судом з прав людини в Страсбурзі. Інакше ризик обмеження носіння релігійної символіки, який процвітає в приватному секторі, сприятиме усуненню мусульманських жінок з місць працевлаштування, тим самим ставлячи перед ними вибір між своїм основним правом на релігійне вираження і доступом до ринку праці.

Схожий підхід, заснований на балансі конфлікту інтересів, знаходимо в американській справі мусульманки Саманти Ілоф, яка не була прийнята на роботу в магазин одягу Abercrombie \& Fitch через те, що іï хіджаб не відповідає дрес-коду компанії. Верховний суд США постановив, що компанія, відмовившись дозволити їй носити головний убір (як важливу частину їі віри), порушила Розділ VII Закону про громадянські права 1964 р., який зобов'язує роботодавця не відмовляти в працевлаштуванні кандидата, керуючись небажанням створити умови для релігійної практики [6]. Сам факт, що головний убір не відповідає загальному дрес-коду компанії, був не достатнім. Тому, принаймні в цьому контексті, американське право більше захищає релігійну практику, ніж закон, що застосовується в Європейському Союзі.

Суд ЄС повинен з'ясувати, чи досягнутий прийнятний баланс між інтересами співробітників, які сповідують свою релігію на роботі й діловими потребами роботодавця. При цьому ще не з'ясовано, якою мірою політика загального нейтралітету для всіх працівників, незалежно від того, чи є у них контакт 3 клієнтами, може вважатися об'єктивно виправданою законною метою. Однак Суд $Є С$ не робить цього, як буде пояснено далі. Фактично свобода ведення бізнесу домінує в аргументації Суду ЄС в справі Ахбіти, тоді як інтереси працівника та ключове людське право на виявлення своєї релігії повністю відсутні.

Варто вказати, що в ст. 9 Європейської Конвенції про захист прав людини і основоположних свобод зазначені легітимні цілі обмежень (охорона громадської безпеки та публічного порядку, здоров'я чи моралі, захист прав і свобод інших осіб). У відповідності до статті 14 цієї ж Конвенції, 
заходи, що мають нелегітимну мету, повинні розглядатися як дискримінаційні [7].

Згідно зі ст. 18.3 Міжнародного пакту про громадянські та політичні права, держава може обмежувати деякі конкретні права, включаючи права на прояв думки, совісті та релігії, а також на свободу вираження поглядів, але лише для певних конкретних законних цілей: охорона суспільної безпеки, порядку, здоров'я і моралі, так само як і основних прав та свобод інших осіб [8]. Однак нейтралітету немає серед указаних цілей. Відсутність загальноєвропейського консенсусу або загального стандарту щодо захисту релігійних поглядів людини призвело до того, що Суд СС надає державам свободу розсуду ведення обмежень на право виявляти свою релігію відповідно до статті 9 Конвенції.

Дійсно, працівники можуть носити релігійні символи, якщо немає вагомих причин для їхньої заборони. Так, роботодавці можуть навести вагомі причини для такого обмеження, наприклад, вимоги захисту здоров'я й забезпечення безпеки в лікарняному відділенні, як це було в справі 3 медсестрою Чаплін, яка працювала в геріатричному відділенні, де існував ризик того, що неспокійний пацієнт може схопитися за ланцюжок та потягнути за нього, тим самим поранивши себе або медсестру, або що хрестик торкнеться відкритої рани пацієнта [5]. У випадку з пані Чаплін ці обмеження, імовірно, були пропорційними та за своєю суттю більш значущими, ніж ті, що застосовувалися до пані Евейди, яка працювала у відділі реєстрації пасажирів в аеропорту.

На думку міжнародної правозахисної організації Amnesty International i ENAR, нейтралітет компанії не є об'єктивно обгрунтованим для того, щоб по-різному ставитися до працівників, які виявляють свою релігію або переконання через видимі символи або одяг на робочому місці. Крім цього, Amnesty International та ENAR стверджують, що загальна вимога, яка висувається до всіх працівників для дотримання суворої політики релігійного та політичного нейтралітету і яка не бере до уваги специфіку чи контекст діяльності, не відповідає критерію визначення професійних вимог відповідно до статті 4.1 Директиви 2000/78 / СС - і тому звільнення пані Ахбіти на основі внутрішньої політики компанії, яка забороняє релігійні, філософські та політичні символи, є прямою дискримінацією через релігію або переконання відповідно до статті 2 (2) (а) Ради Директива 2000/78 / СС [9].

Генеральний адвокат Дж. Кокотт у цій справі дійшла висновку, що приватне підприємство може правомірно проводити політику нейтралітету й зобов'язувати своїх працівників не виявляти ознаки будь-якої релігії, переконань або політичних поглядів на робочому місці (пункт 76). Тому позиція пані Ахбіти в компанії вимагає дотримання дрес-коду, установленого роботодавцем (пункт 84). При цьому вона зазначила у своєму висновку, що при вирішенні подібних справ Судом ЄС необхідно враховувати такі чинники: розмір і виразність релігійного символу, характер діяльності працівника, контекст, у якому виконується ця діяльність, і 
національну ідентичність відповідної держави-члена [10]. Такий підхід, безсумнівно, є не сприятливим для мусульманських жінок. Адже, по суті, хрестик пані Евейди був не помітним та не міг пошкодити тї професійному вигляду, тоді як головний убір пані Ахбіти демонструє видимий релігійний символ і може піддаватися суворішим заборонам у приватному секторі.

Справа Саміри Ахбіти залишає місце для дискусії про гіпотетичне існування прямої дискримінації, незважаючи на заявлену й намічену політику релігійного нейтралітету компанії [11, с. 417]. Неупереджений погляд свідчить про те, що на одній чаші терезів знаходиться бажання пані Ахбіти проявляти свою релігію, а на іншій - бажання компанії сформувати певний корпоративний імідж. Наслідки, з якими зіткнулися пані Ахбіта, що виникли внаслідок загальної заборони на носіння видимого релігійного одягу в G4S, викликають занепокоєння щодо пропорційності цього заходу. Зокрема, заборона призвела до звільнення пані Ахбіти без будь-якої спроби з боку роботодавців вжити заходів щодо переведення працівника, який бажає носити одяг з релігійною символікою, на іншу посаду, яка не пов'язана 3 візуальним контактами 3 клієнтами. Рішення Суду ЄС легітимізує дискримінацію, зокрема щодо мусульманських жінок, тим самим порушуючи принцип рівності. Таким чином, ставлення до людських спільнот за їхньою релігійною приналежністю, яким притаманна певна зовнішня релігійна орієнтація, не сприятиме зміцненню толерантності в суспільстві в контексті мультирелігійності сучасної Європи.

Висновки. Свобода релігії, як і заборона дискримінації є правом людини, захищеним Європейською конвенцією про захист прав людини і основних свобод. Свобода сповідувати свою релігію підлягає лише таким обмеженням, що встановлені законом і є необхідними в демократичному суспільстві в інтересах громадської безпеки, для охорони публічного порядку, здоров'я чи моралі або для захисту прав і свобод інших осіб. Місце релігії в європейському публічному просторі відрізняється в різних державах-членах завдяки їх конституційним традиціям і моделям державноцерковних відносин. Національні суди по-різному розуміють і застосовують принцип нейтралітету підприємства, бо не існує європейського консенсусу 3 цього питання та єдиних європейських стандартів щодо місця релігійних символів на робочих місцях.

Узагалі, прецедентна практика, розроблена Судом ЄС та національними судами стосовно свободи релігії та заборони релігійної дискримінації дозволяє приватним компаніям вводити заборони на носіння релігійних символів на робочому місці, зокрема для працівників, які мають контактні робочі місця, лише якщо роботодавець може довести, що такий захід є доречним i необхідним у конкретних обставинах. Якщо проводити паралелі між носінням хреста і хіджабів або тюрбанів, то виявляється, існує певна невідповідність підходу з тим, що було прийнято Європейським судом з прав людини у справі Евейди проти Сполученого Королівства, коли політика нейтралітету авіакомпанії не була оцінена Судом і було вирішено, що невеликий хрестик пані Евейди ніяк не впливатиме на корпоративний імідж компанії. У разі сумнівів невеликий за розміром релігійний символ у формі сережки, браслету 
або намиста швидше за все буде дозволений, на відміну від помітного покриття голови, наприклад, капелюхом, тюрбаном або хусткою. Тому досі нерозв'язаними залишаються питання про те, чи є обмеження конкретного релігійного символу, в аналізованому випадку хіджаб пані Ахбіти, на робочому місці необхідним і пропорційним для захисту приватного нейтралітету й чи впливає цей релігійний атрибут на виконання роботи.

\section{Використані джерела:}

1. Charter of fundamental rights of the European Union 2000/C 364/01. URL : https://www.europarl.europa.eu/charter/pdf/text_en.pdf (дата звернення: 30.06.2019).

2. EU Equal Treatment Framework Directive 2000/78/EC. URL : https://eurlex.europa.eu/legal-content/EN/TXT/?uri=celex\%3A32000L0078 (дата звернення: 30.06.2019).

3. Achbita and another v G4S Secure Solutions NV : Case C-157/15.2017. URL: http:// curia.europa.eu/juris/document/document.jff?docid=188852\&pageIndex $=0 \&$ doclang=EN\&=1 (дата звернення: 30.06.2019).

4. Bougnaoui and another $\mathrm{v}$ Micropole SA: Case C-188/15.2017. URL: http:// curia.europa.eu/juris/document/document.jff?docid $=188853 \&$ pageIndex $=0 \&$ doclang=EN (дата звернення: 30.06.2019).

5. Eweida and others v United Kingdom. Judgment of the European Court of Human Rights (Fourth Section). 15 January 2013 (Applications №№ 48420/10, 59842/10, 51671/10 and 36516/10). URL: https://hudoc.echr.coe.int/eng\# \{\%22itemid \%22:[\%22001-115881\%22]\} (дата звернення: 30.06.2019).

6. Case of EEOC v. Abercrombie \& Fitch Stores. URL: https:/ / www.leagle.com/ decision/infco20131001061 (дата звернення: 30.06.2019).

7. The Convention for the Protection of Human Rights and Fundamental Freedoms. URL : https://www.echr.coe.int/Documents/Convention_ENG.pdf (дата звернення: 30.06.2019).

8. International Covenant on Civil and Political Rights. URL: https://www.ohchr.org/en/professionalinterest/pages/ccpr.aspx (дата звернення: 30.06.2019).

9. Wearing the headscarf in the workplace : Observations on discrimination based on religion. URL: https://www.amnesty.org/download/Documents/ EUR0150772016ENGLISH.PDF (дата звернення: 30.06.2019).

10. Opinion of Advocate General Kokott. Samira Achbita and Centrum voor gelijkheid van kansen en voor racismebestrijding v. G4S Secure Solutions NV., 31 May 2016. URL : http://curia.europa.eu/juris/document/document.jsf?docid=179082 (дата звернення: 30.06.2019).

11. José Rafael Marín Aís. Freedom of Religion in the Workplace v. Freedom to Conduct a Business, the Islamic Veil Before the Court of Justice: Ms. Samira Achbita Case. European Papers. 2018. Vol. 3. pp. 409-417. URL: http://www.europeanpapers.eu/ es/system/files/pdf_version/EP_EF_2018_I_007_Jose_Rafael_Marin_Ais_3.pdf (дата звернення: 30.06.2019).

\section{References:}

1. Charter of fundamental rights of the European Union 2000/C 364/01. URL : https://www.europarl.europa.eu/charter/pdf/text_en.pdf (data zvernennia: 30.06.2019). 
2. EU Equal Treatment Framework Directive 2000/78/EC. URL : https://eurlex.europa.eu/legal-content/EN/TXT/?uri=celex\%3A32000L0078 (data zvernennia: 30.06.2019).

3. Achbita and another v G4S Secure Solutions NV : Case C-157/15.2017. URL : http:/ / curia.europa.eu/juris/document/ document.jsf?docid $=188852 \&$ pageIndex $=0 \&$ doclang=EN\&=1 (data zvernennia: 30.06 .2019 ).

4. Bougnaoui and another $\mathrm{v}$ Micropole SA: Case C-188/15.2017. URL: http:/ / curia.europa.eu/juris/document/ document.jsf?docid $=188853 \&$ pageIndex $=0$ \& doclang=EN (data zvernennia: 30.06.2019).

5. Eweida and others v United Kingdom. Judgment of the European Court of Human Rights (Fourth Section). 15 January 2013 (Applications №№ 48420/10, 59842/10, 51671/10 and 36516/10). URL: https://hudoc.echr.coe.int/eng\# $\{\% 22$ itemid $\% 22$ :[\%22001-115881\%22]\} (data zvernennia: 30.06.2019).

6. Case of EEOC v. Abercrombie \& Fitch Stores. URL: https://www.leagle.com/ decision/infco20131001061 (data zvernennia: 30.06.2019).

7. The Convention for the Protection of Human Rights and Fundamental Freedoms. URL : https://www.echr.coe.int/Documents/Convention_ENG.pdf (data zvernennia: 30.06.2019).

8. International Covenant on Civil and Political Rights. URL: https://www.ohchr.org/en/professionalinterest/pages/ccpr.aspx (data zvernennia: 30.06.2019).

9. Wearing the headscarf in the workplace : Observations on discrimination based on religion. URL: https://www.amnesty.org/download/Documents/ EUR0150772016ENGLISH.PDF (data zvernennia: 30.06.2019).

10. Opinion of Advocate General Kokott. Samira Achbita and Centrum voor gelijkheid van kansen en voor racismebestrijding v. G4S Secure Solutions NV., 31 May 2016. URL: http://curia.europa.eu/juris/document/document.jsf?docid=179082 (data zvernennia: 30.06.2019).

11. José Rafael Marín Aís. Freedom of Religion in the Workplace v. Freedom to Conduct a Business, the Islamic Veil Before the Court of Justice: Ms. Samira Achbita Case. European Papers. 2018. Vol. 3. pp. 409-417. URL: http://www.europeanpapers.eu/ es/system/files/pdf_version/EP_EF_2018_I_007_Jose_Rafael_Marin_Ais_3.pdf (data zvernennia: 30.06.2019).

Стаття надіӥшла до редколегї 10.04.2019

Животовская И. Ю., кандидат юридических наук, старший преподаватель кафедры конституционного права

Национального университета «Одесская юридическая академия»

(г. Одесса, Украина)

\section{ЗАПРЕТ ДИСКРИМИНАЦИИ НА НОШЕНИЕ РЕЛИГИОЗНЫХ СИМВОЛОВ В СУДЕБНОЙ ПРАКТИКЕ ЕВРОПЕЙСКИХ РЕГИОНАЛЬНЫХ СУДОВ}

В статье автор анализирует судебную практику Суда Европейского Союза, направленного на рассмотрение дел по демонстрации работниками религиозных символов на рабочем месте (Achbita v G4S Secure Solutions NV и Bougnaoui v 
Micropole SA), касающихся религиозной дискриминации в соответствии с Директивой о равном отношении 2000/78/ЕС. Согласно международным конвенциям по правам человека, стремление частной компании к нейтральной политике не может быть поводом для ограничений права на свободу вероисповедания работника на рабочем месте. Однако Суд установил, что при соответствующих обстоятельствах компания имеет право на ведение такой политики, которая, в свою очередь, имеет негативные последствия для значительной части общества - особенно для мусульман, сикхов и иудеев, которые сталкиваются с серьезной дискриминацией при трудоустройстве. Особенное внимание в статье уделяется опыту Европейского Суда по правам человека по рассмотрению аналогичных дел.

Ключевые слова: права человека, свобода вероисповедания, религиозная дискриминация, религиозные символы, нейтралитет, пропорциональность, принцип равности.

Zhyvotovska I.,

the prohibition of discrimination on the basis of wearing religious symbols in the judicial practice of European Regional courts

(Odessa, Ukraine)

\section{PROHIBITION OF DISCRIMINATION AGAINST THE WEARING OF RELIGIOUS SYMBOLS IN THE JURISPRUDENCE OF EUROPEAN REGIONAL COURTS}

The manifestation of religion or belief by wearing of visible religious symbols or clothing in public spaces is an integral part of the freedom of religion. According to the international human rights conventions, the pursuit of a private company for neutral policies cannot be a reason for restriction on freedom of religion in the workplace. However, the European Court of Justice in the cases of Achbita v G4S Secure Solutions NV and Bougnaoui $\mathrm{v}$ Micropole SA has established that under certain circumstances, established by law, a company has the right to pursue such a policy but it also can have a negative impact for a large part of society - especially for Muslims, Sikhs and Jews who face serious discrimination in employment. In Western countries, religious discrimination in labor relations is quite common for Muslim women.

The article also discusses the judgment in the case of Eweida and Others v the United Kingdom, handed down by the European Court of Human Rights on 15 January 2013. The applicant complained that domestic law failed adequately to protect their right to manifest their religion. The ECHR concluded that the dismissal of women from work violated her rights under the provisions of the 9th European Convention on Human Rights which guarantees the freedom of conscience and religion. Although Nadia Eweida's victory shows that Christians can see wearing a cross at work as part of behaving in accordance with their religion, the court's decision was based on special circumstances - including the fact that a discreet cross would not have adversely affected British Airways' public image.The European Court of Human Rights deals exclusively with cases involving violations of the fundamental human rights enshrined in the Convention for the Protection of Human Rights and fundamental freedoms. Labor law is not included in the list of fundamental and regulatory national and international documents. The European Court of Justice ruled in favour of the private company G4S Secure Solutions NV and on the contrary The European 
Court of Human Rights issued its keenly awaited judgment in favour of Nadia Eweida. In essence, all this shows that the ECHR takes freedom of religion more seriously.

Key words: human rights, freedom of religion, religious discrimination, religious symbols, neutrality, proportionality, principle of equality.

\section{DOI \\ УДК 342.724 (4)}

\section{О. М. Литвинов,} доктор юридичних наук, кандидат філософських наук, доцент, завідувач кафедри соціальногуманітарних дисциплін і професійної психології Луганського державного університету внутрішніх справ імені Е. О. Дідоренка

(м. Сєвєродонецьк, Україна)

e-mail: 1littvvnn@gmail.com iD https://orcid.org/0000-0002-2257-22245

\section{ПРОБЛЕМА РЕЛІГІЙНОЇ СВОБОДИ ЯК ПИТАННЯ ФОРМУВАННЯ ПРАВОСВІДОМОСТІ: КУЛЬТУРНО-ІСТОРИЧНІ ЗАСАДИ Й АКТУАЛЬНИЙ ЗМІСТ}

У статті розглядається проблема релігійної свободи в контексті прав людини (людських прав). Досліджується історичний аспект взаємовпливу релігійної (іудео-християнської) та правової (буржуазної) свідомості в процесі формування ідеї невід'ємних прав людини в європейській культурі. Висувається думкагіпотеза, згідно якої релігію в цілому слід розуміти й тлумачити 3 точки зору їі об'єднучої ролі, а не навпаки. Шляхами до такого розуміння є етимологія (слово «релігія» означає «зв'язок»), а також тлумачення релігійної свободи як одного із засадничих прав людини (поняття «право» в Новий час визначається через поняття «свобода»). Актуальність теми визначається реальним значенням релігійного фактора в сучасному світі, його впливом на культурний та політичний розвиток країн і народів, що сьогодні часто супроводжується конфліктами. Звернення до культурно-історичних джерел ідеї людських прав у філософії права Нового часу (доби Модерну) дозволяє обгрунтувати деякі положення, що пов'язують ідею прав людини з ідеєю релігійної свободи через розуміння рівності прав і свобод кожної людини. Ці ідеї невід'ємних природних прав людини розроблялися насамперед в класичних творах Г. Гроція, Т. Гобса, Б. Спінози, Дж. Лока, Ш. Монтеск'є, 3. Пуфендорфа, І. Канта, Г. Гегеля та деяких інших мислителів Нового часу. Усі ці ідеї в цілому, об'єднані поняттям «свобода», дозволяють обгрунтовувати доцільність загальної постановки питання про можливість використання поняття релігійної свободи для вирішення інших проблем культурного розвитку, перш за все правового. Важливим фактором $є$ такий, що саме ці правові ідеї є основою сучасного конституціоналізму і їх відбито в Конституціях переважної більшості держав світу.

Ключові слова: свобода, релігійна свобода, право, людські права (права людини), рівність, правосвідомість, філософія права, культура, історія.

Постановка проблеми. Проблеми релігійного життя та зокрема релігійної свободи в різноманітних ії проявах набувають у сучасному світі (с) Литвинов О. М., 2019 